\title{
PROBLEM STRONY PODMIOTOWEJ PRZESTĘPSTWA ZNĘCANIA SIĘ NAD ZWIERZĘTAMI NA GRUNCIE USTAWY Z 21 SIERPNIA 1997 R. O OCHRONIE ZWIERZĄT
}

\begin{abstract}
Streszczenie. Celem artykułu jest podjęcie tematyki przestępstwa znęcania się nad zwierzętami, określonego w ustawie o ochronie zwierząt. Poddane analizie zostały znamiona strony podmiotowej omawianego przestępstwa. Przedstawiono stanowiska przedstawicieli doktryny prawa karnego oraz poglądy występujące w orzecznictwie, szczególnie Sądu Najwyższego.

Słowa kluczowe: ustawa o ochronie zwierząt, zabijanie zwierząt, znęcanie się nad zwierzętami, zamiar bezpośredni, zamiar ewentualny.
\end{abstract}

\section{THE PROBLEM OF THE SUBJECTIVE SIDE OF THE CRIME OF KILLING AND ABUSING ANIMALS UNDER THE ACT OF AUGUST 21, 1997 ON THE PROTECTION OF ANIMALS}

\begin{abstract}
The aim of the article is to discuss the crimes of killing and abusing animals set out in the Animal Protection Act. The characteristics of the subjective side of the analyzed acts were analyzed. Attention was drawn to the problem related in particular to the subject of the crime of animal abuse. The positions of the representatives of the criminal law doctrine and views appearing in the jurisprudence, especially of the Supreme Court, were presented.
\end{abstract} intention.

Keywords: Animal Protection Act, killing animals, animal abuse, direct intention, possible

\section{WPROWADZENIE}

Stosunek ludzi do zwierząt charakteryzuje się wysoką ambiwalencją. Trafną tego ilustracją może być przykład krów, które w Indiach otaczane są czcią i cieszą się nietykalnością, zaś w Europie i Ameryce Północnej traktowane są jako „chodzące bańki mleka lub hamburgery na czterech nogach" (Serpell 1999, 7). Ambiwalencję tę można dostrzec nie tylko w odmiennym podejściu ludzi do zwierząt gospodarskich i domowych pupili, ale również w stosunku człowieka do gatunków z łatwością określanych jako „czworonożnych przyjaciól”. W niektórych środowiskach trzymanie psów na kilkumetrowym, żelaznym łańcuchu, także podczas

*Uniwersytet Łódzki, Wydział Prawa i Administracji, a.fijaukowska@gmail.com 
zimy, jest zachowaniem nie budzącym kontrowersji. Warto jednak zauważyć, że wrażliwość społeczeństwa na cierpienie zwierząt wciąż wzrasta. Zakres świadomości obowiązków ciążących na właścicielach zwierząt oraz zakazu zadawania zwierzętom bólu również ulega rozszerzeniu. Polski ustawodawca w obliczu takich zmian w mentalności społeczeństwa także nie pozostał bierny. W ustawie z 21 sierpnia 1997 r. o ochronie zwierząt (tekst jedn. Dz.U. 2020 poz. 638; dalej: u.o.z.) zawarł postulat, zgodnie z którym człowiek winien jest zwierzęciu poszanowanie, ochronę i opiekę. Tym samym ustawodawca dał wyraz, że zwierzętom należy się szacunek i ochrona choćby ze względu na fakt zdolności do odczuwania cierpienia. Życie zwierząt, wolne od cierpienia, zostało zabezpieczone zawartymi w ustawie przepisami karnymi, typizującymi przestępstwa zabijania i znęcania się nad zwierzętami. To właśnie ich problematyka stanie się przedmiotem analizy w niniejszym artykule.

Ponieważ ustawa o ochronie zwierząt stanowi obecnie najważniejszy akt w polskim porządku prawnym odnoszący się do prawnokarnej ochrony zwierząt, dokonanie analizy przepisów określających przestępstwo znęcania się nad zwierzętami wraz z odniesieniem do typu kwalifikowanego pozostaje kluczową kwestią. Nie ulega bowiem wątpliwości, że jeden z problemów związanych z przestępstwami stypizowanymi w ustawie o ochronie zwierząt pozostaje szczególnie kontrowersyjny. Mowa tutaj o określeniu strony podmiotowej omawianego czynu zabronionego.

\section{ZAMIAR EWENTUALNY PRZY PRZESTĘPSTWIE ZNĘCANIA SIE NAD ZWIERZĘTAMI}

Zgodnie z art. 35 u.o.z. zarówno w przypadku zabijania zwierząt, jak i znęcania się nad nimi, warunkiem poniesienia odpowiedzialności karnej za te czyny jest umyślność. Jak wskazuje M. Mozgawa, o ile przy zabijaniu zwierząt dopuszcza się zarówno zamiar bezpośredni, jak i ewentualny, tak w przypadku znęcania się w orzecznictwie sądowym i w literaturze prawniczej dominuje pogląd, że możliwy jest jedynie zamiar bezpośredni (Mozgawa 2017, 80). Podobna sytuacja występuje w przypadku znęcania się ze szczególnym okrucieństwem.

Takie stanowisko przedstawił W. Radecki twierdząc, że znęcanie się nad zwierzętami może być działaniem lub zaniechaniem dokonanym jedynie z zamiarem bezpośrednim. Autor ten zaś w odniesieniu do typu kwalifikowanego przestępstwa znęcania się nad zwierzętami, wzbogaconego o znamię ,,szczególnego okrucieństwa" czynu sprawcy, dopuszcza możliwość zaistnienia zamiaru ewentualnego. W. Radecki uzasadnia to twierdzenie w ten sposób, że sprawca decydując się na traktowanie zwierzęcia w sposób uznany przez przeciętnego człowieka za wyjątkowo brutalny, z góry godzi się na to, że jego zachowanie może zostać ocenione jako szczególnie okrutne (Radecki 2015, 227). O ile dopuszczenie 
przez autora w przypadku możliwości popełnienia znęcania się nad zwierzętami jedynie z zamiarem bezpośrednim wydaje się być przykładem dość popularnego stanowiska w tej sprawie, tak uznanie popełnienia typu kwalifikowanego tego przestępstwa za możliwe, także z zamiarem ewentualnym, stanowi pogląd niszowy, budzący pewne wątpliwości. Należy mieć na względzie, iż „szczególne okrucieństwo" jest znamieniem zawierającym zarówno element przedmiotowy, jak i podmiotowy, który odnosi się do szczególnego nastawienia sprawcy (Mozgawa, Budyn-Kulik, Dudka, Kulik 2011, 49-50). Zgodnie z definicją zawartą w art. 4 pkt 12 u.o.z. szczególne okrucieństwo oznacza przedsiębranie przez sprawcę działań charakteryzujących się drastycznością form i metod, a zwłaszcza działanie w sposób wyszukany lub powolny, obliczony z premedytacją na zwiększenie rozmiaru cierpień i czasu ich trwania. Jak wskazuje M. Budyn-Kulik, w przypadku zamiaru ewentualnego godzenie się dotyczy skutku, który dla sprawcy jest jedynie uboczny w stosunku do podstawowego celu jego działania (Budyn-Kulik 2021). Trudno zatem wyobrazić sobie sytuację, w której sprawca godzi się na mogący wystąpić stan rzeczy, który obejmuje szczególnie drastyczne zachowanie względem zwierzęcia. Ponadto definicja zawarta w art. 4 pkt 12 u.o.z. nie jest w pełni wyczerpująca i pozostawia niedookreślone znamię ,szczególnego okrucieństwa”, jednak nie ulega wątpliwości, że odnosi się do działania wyjątkowo brutalnego, powodującego odrazę. Zatem uznanie, że w przypadku znęcania się nad zwierzętami ze szczególnym okrucieństwem dopuszczalny jest również zamiar ewentualny, może rodzić poważne zastrzeżenia.

W literaturze można spotkać zupełnie odmienny pogląd wyrażony przez M. Mozgawę, zgodnie z którym dopuszczalne jest umyślne popełnienie przestępstwa znęcania się w obu postaciach zamiaru. Jako przykład takiej sytuacji autor przedstawia zachowanie kierowcy pojazdu transportującego żywe zwierzęta do rzeźni, który - aby zdążyć na czas do punktu docelowego - nie zatrzymuje się w celu napojenia zwierząt i tym samym powoduje ich cierpienie (Mozgawa 2017, 81). Wydaje się więc, że możliwa jest sytuacja, w której sprawca zmierza do pewnego określonego celu i godzi się na to, że swoim zachowaniem jednocześnie realizuje znamiona typu czynu zabronionego, a zatem ma miejsce zamiar ewentualny. Warto w tym miejscu odwołać się również do dorobku doktryny prawa karnego powstałego na gruncie analizy przestępstwa z art. $207 \S 1$ ustawy z dnia 6 czerwca 1997 r. - Kodeks karny (tekst jedn. Dz.U. 2020 poz. 1444 ze zm.; dalej: k.k.). Należy stwierdzić, że przełożenie wykładni znęcania się nad człowiekiem z Kodeksu karnego na znęcanie się nad zwierzętami z ustawy o ochronie zwierząt nie stanowi najbardziej pożądanego rozwiązania, jednak do momentu, kiedy prawna regulacja przestępstw przeciwko zwierzętom nie będzie sama pozwalała rozwiać wszelkich wątpliwości, warto odwołać się do dorobku, który przez lata powstawał w odniesieniu do typu czynu zabronionego z Kodeksu karnego, określonego takim samym znamieniem czasownikowym. Warto zatem przytoczyć stanowisko A. Wąska, do którego odwołuje się również M. Mozgawa, odnoszące 
się do dopuszczenia jedynie zamiaru bezpośredniego w przypadku znęcania się podkreślając: „twierdzenie, że pojęcie znęcania się jest tak dalece zabarwione pod względem podmiotowym, jest po prostu nadinterpretacją" (Wąsek 2004, 988). W tym przypadku rozstrzygnięcie wypracowane na gruncie art. $207 \S 1$ k.k. wydaje się rozstrzygać problem związany z dopuszczeniem zamiaru ewentualnego znęcania się nad zwierzętami. Takie uzasadnienie możliwości popełnienia omawianego przestępstwa w obu postaciach zamiaru wydaje się trafne również z tego powodu, iż w ustawie o ochronie zwierząt został opisany także typ kwalifikowany tytułowego czynu zabronionego, określony przywołanym wcześniej znamieniem „szczególnego okrucieństwa”. Wydaje się zatem, że właśnie ten typ znęcania się nad zwierzętami winien być interpretowany jako mocno zabarwiony pod względem podmiotowym. Taki sam wniosek przedstawia M. Mozgawa twierdząc, iż dopuszczenie się popełnienia tego czynu z zamiarem ewentualnym może budzić poważne zastrzeżenia. Rozumując w ten sposób, autor czyni swoje stanowisko zupełnie sprzecznym z zapatrywaniami przedstawionymi przez W. Radeckiego, wnosząc do dyskusji dotyczącej strony podmiotowej znęcania się nad zwierzętami trafne spostrzeżenia. Autor zwraca uwagę, że w swojej istocie przestępstwo znęcania się nad zwierzętami w typie kwalifikowanym wymaga zachowania wyjątkowo brutalnego, a zatem odnosi się nie tylko do elementu przedmiotowego przestępstwa, ale także do podmiotowego, wyrażającego się w szczególnym nastawieniu sprawcy (Mozgawa 2017, 84). Jest to zatem twierdzenie dalekie od zaakceptowania możliwości wystąpienia zamiaru ewentualnego w przypadku popełnienia przestępstwa znęcania się nad zwierzętami ze szczególnym okrucieństwem. Ponadto wydaje się, że jest to rozwiązanie nie budzące większych wątpliwości. Przedstawienie kontrastujących opinii czołowych, autorów podejmujących tematykę prawnokarnej ochrony zwierząt zdaje się jedynie podkreślać skalę problemu. Warto jednak odnieść się również do innych stanowisk przedstawicieli doktryny, aby dokonać pełnej analizy omawianego problemu.

Inne zapatrywanie na ten temat wyrażają P. Skuczyński i A. Zientara, które to stanowisko popiera również K. Kuszlewicz. Autorzy ci wskazują, że w istocie do umyślnego popełnienia czynu znęcania się nad zwierzętami niezbędny jest zamiar bezpośredni, jednak odnosi się on do samej czynności sprawczej, nie zaś do chęci spowodowania zwierzęciu bólu (Skuczyński, Zientara 2012, 207). Autorzy powołują się na wyrok Sądu Najwyższego z dnia 16 listopada 2009 r. (wyr. SN z 16.11.2009 r., V KK 187/09, LEX Nr 553896). Sąd stwierdził wówczas, że przestępstwo znęcania się nad zwierzętami może zostać popełnione jedynie z zamiarem bezpośrednim, który jednak dotyczy wyłącznie czynności sprawczej. Zatem jeżeli zachowanie sprawcy wyczerpuje znamiona któregoś z czynów opisanych w art. 6 ust. 2 u.o.z., nie jest niezbędne dodatkowe wykazywanie, że bezpośrednim celem sprawcy było spowodowanie cierpienia zwierzęcia. Należy wspomnieć, że w art. 6 ust. 2 u.o.z. znajduje się definicja pojęcia znęcania się nad zwierzętami, do której odnosi się art. 35 ust. 1a u.o.z. Wskazana definicja 
ma złożoną budowę. W pierwszej części składa się z określenia znęcania się nad zwierzętami jako zadawania albo świadomego dopuszczania do zadawania bólu lub cierpień. Drugą część definicji stanowi katalog przykładów zachowań uznanych za znęcanie się nad zwierzętami. Należy uznać, że ze względu na użyte wyrażenie „w szczególności” jest to katalog otwarty. Zatem zachowanie, które nie będzie wprost wyrażone w art. 6 ust. 2 u.o.z., ale będzie polegało na zadawaniu zwierzęciu bólu i cierpienia, powinno również zostać uznane za znęcanie się. Jak podkreślają P. Skuczyński i A. Zientara, przyjęcie stanowiska prezentowanego przez Sąd Najwyższy ułatwi w znacznym stopniu ściganie osób, które dopuściły się jakiegokolwiek zachowania uznanego za znęcanie się nad zwierzętami. Bowiem nie będzie niezbędne wykazanie, że ,sprawca zamiarem bezpośrednim obejmował także zadawanie zwierzęciu bólu lub cierpienia" (Skuczyński, Zientara 2012, 207). W mojej opinii jest to słuszne podejście, będące próbą odnalezienia „złotego środka” pomiędzy stanowiskami prezentowanymi między innymi przez M. Mozgawę i W. Radeckiego.

Warto jednak odnieść się również do glosy M. Gabriela-Węglowskiego, dotyczącej wspomnianego wyroku Sądu Najwyższego z 16 listopada 2009 roku. Autor wskazuje, iż twierdzenie Sądu Najwyższego, że dopuszczalne jest znęcanie się nad zwierzętami jedynie z zamiarem bezpośrednim, pozostaje bardzo dyskusyjne. W przeprowadzonej przez siebie analizie autor nie odnosi się jednak do kluczowego w tej sprawie twierdzenia Sądu Najwyższego, iż ,zamiar odnosi się więc do samej czynności sprawczej, a nie do spowodowania cierpień lub bólu” (wyr. SN z 16.11.2009 r., V KK 187/09, LEX Nr 553896). Twierdzi natomiast, iż ,zgodnie z komentowanym tu orzeczeniem Sądu Najwyższego, aby doszło do popełnienia przestępstwa z art. 35 ust. 1 u.o.z., każdy z powyższych czynów wymaga zamiaru bezpośredniego. A zatem sprawca musi chcieć znęcać się nad zwierzęciem" (Gabriel-Węglowski 2010). M. Gabriel-Węglowski wyraża pogląd, zgodnie z którym w przypadku znęcania się nad zwierzętami dopuszczalny powinien być również zamiar ewentualny. Jako uzasadnienie tego twierdzenia autor przedstawia fakt, iż sam ustawodawca tworząc w art. 6 ust. 2 u.o.z. otwarty katalog zachowań uznanych za znęcanie się. Zatem sąd powinien stwierdzić jedynie, czy ustalenia faktyczne pokrywają się z pewnym typem zachowania. W przypadku niektórych ze wskazanych we wspomnianym katalogu zachowań bez wątpienia można dopuścić zamiar ewentualny, między innymi przewożenie zwierząt w sposób powodujący ich zbędne cierpienie i stres.

Mimo iż w mojej opinii autor przedstawia słuszne stanowisko dotyczące dopuszczalności zamiaru ewentualnego przy przestępstwie znęcania się nad zwierzętami, przedstawiane przez niego uzasadnienie poglądów nie wydaje się w zupełności przekonywające. Autor, nie uznając rozwiązań przedstawianych w omawianym wyroku Sądu Najwyższego za trafne, nie odniósł się do całości do orzeczenia, w szczególności do określenia, iż zamiar bezpośredni dotyczy jedynie czynności sprawczej. Ponadto przedstawione przez autora uzasadnienie 
poglądów opiera się niemal w zupełności na odwołaniu do egzemplifikacji zawartej w art. 6 ust. 2 u.o.z., gdyż w istocie niektóre z określonych tam przykładów zachowań wydają się być możliwe do dokonania z zamiarem ewentualnym. Należy jednak pamiętać, że katalog z art. 6 ust. 2 u.o.z. ma charakter otwarty i stanowi jedynie część definicji znęcania się nad zwierzętami. Zatem twierdzenie, iż zadaniem sądu podczas rozstrzygania o odpowiedzialności karnej sprawcy jest jedynie badaniem, czy ustalenia faktyczne odpowiadają typowi zachowania przewidzianego w art. 6 ust. 2 u.o.z. uznać należy za błędne. Istnieje bowiem wiele możliwości zachowań, które nie pokrywają się z przypadkiem wskazanym expressis verbis w ustawie, a jednak stanowią przykład znęcania się nad zwierzętami.

Odnosząc się do poglądów M. Gabriela-Węglowskiego, należy wspomnieć również o przeprowadzonej przez tego autora analizie linii orzeczniczej dotyczącej strony podmiotowej znęcania się nad zwierzętami. Autor podkreślił, że na przestrzeni lat poglądy dotyczące omawianego problemu ulegały zmianie. Stwierdza, iż

taka konstatacja pozwala, a nawet nakazuje, szczególnie wnikliwe rozważanie, czy przynajmniej w przypadku niektórych typów czynów zabronionych dotyczących znęcania się, rzeczywiście zasadne jest wykluczenie przestępności czynu w razie ustalenia zamiaru ewentualnego po stronie podmiotowej (Gabriel-Węglowski 2019).

Autor ten korzysta z dorobku nauki powstałego na podstawie analizy przestępstwa znęcania się określonego w kodeksie karnym. Powołuje się bowiem na wyrok Sądu Okręgowego w Piotrkowie Trybunalskim z 6 marca 2018 r., w którym stwierdzono w odniesieniu do art. 207 k.k. że

stroną podmiotową znęcania się jest umyślność, która w zasadzie występuje w postaci zamiaru bezpośredniego, wyrażającego się w chęci wyrządzenia krzywdy fizycznej lub moralnej, dokuczenia, poniżenia itp. - obojętnie z jakich pobudek. Nie można jednak wyłączyć popełnienia tego przestępstwa $\mathrm{z}$ zamiarem ewentualnym. W takim wypadku niezbędne jest ustalenie na podstawie konkretnych okoliczności, że sprawca, dążąc bezpośrednio do innego celu, jednocześnie godził się na wyrządzenie pokrzywdzonemu dotkliwych przykrości i cierpień. O ile zgodzić należy się z koniecznością ustalenia strony przedmiotowej czynu z art. 207 § 1 k.k. w oparciu o kryteria obiektywne, o tyle kategoryczny pogląd co do znamion strony podmiotowej ograniczający ją jedynie do zamiaru bezpośredniego, uznać należy co najmniej za wątpliwy (wyr. SO w Piotrkowie Trybunalskim z 6.03.2018 r., IV Ka 73/18, LEX Nr 2503938).

M. Gabriel-Węglowski jako kolejny autor odniósł się do dorobku doktryny wypracowanego na gruncie art. $207 \S 1$ k.k. W tym przypadku należy przyznać autorowi słuszność. Przeprowadzone rozważania i przedstawione argumenty wpisują się w nurt dopuszczenia zamiaru ewentualnego przy znęcaniu się nad zwierzętami ze względu na dobro zwierząt. Należy wszakże pamiętać, iż ochrona życia zwierząt, wolnego od cierpienia, stanowi główny cel ustawy o ochronie zwierząt.

Warto odwołać się również do prezentowanej przez K. Kuszlewicz linii orzeczniczej dotyczącej rozumienia zamiaru bezpośredniego sprawcy przy znęcaniu się nad zwierzętami. Zgodnie z tą analizą przyjęcie, że zamiar bezpośredni 
odnosi się do chęci sprawienia zwierzęciu cierpienia, prowadzi „do zdecydowanego zawężenia ochrony zwierząt przed niehumanitarnym traktowaniem, która to jest pierwszorzędnym celem ustawy o ochronie zwierząt”" (Kuszlewicz 2018). Autorka w swojej analizie powołuje się na wspomniany wcześniej wyrok Sądu Najwyższego z 16 listopada 2009 r., a także między innymi na wyrok tegoż Sądu z 13 grudnia 2016 r. Sąd wskazał wówczas, że

zamiar bezpośredni w zakresie tego przestępstwa winien być badany jednak w odniesieniu do samej czynności sprawczej, a nie woli zadania cierpień lub bólu zwierzęciu. To ustawodawca sam przesądził, że wymienione $w$ tych punktach zachowania są znęcaniem się, czyli powodują ból lub cierpienie (wyr. SN z 13.12.2016 r., II KK 281/16, LEX Nr 2237277).

To stanowisko Sądu Najwyższego znalazło także odzwierciedlenie w wyroku z 7 lipca 2020 r., zgodnie z którym

\begin{abstract}
Sąd Najwyższy stoi jednoznacznie na stanowisku, że do bytu przestępstwa znęcania się nad zwierzętami nie jest konieczne dążenie sprawcy wprost do zadania zwierzęciu cierpienia. Jakkolwiek w swoich judykatach podkreślał, że co prawda przestępstwo znęcania się nad zwierzętami w swojej konstrukcji wymaga zaistnienia po stronie sprawcy winy umyślnej w zamiarze bezpośrednim, to zamiar ten badać należy w odniesieniu do samej czynności sprawczej, nie zaś do woli sprawcy zadania bólu lub cierpienia zwierzęciu. Ta dość nieoczywista z pozoru konstrukcja zdecydowanie poszerza ochronę zwierząt przed znęcaniem się, jednak wciąż spotyka się z niewłaściwym rozumieniem. Często organy ścigania lub sądy poprzestają tylko na wskazaniu, że elementem koniecznym tego przestępstwa jest zamiar bezpośredni, pomijając okoliczności, wobec których powinien on zostać stwierdzony. Sąd Najwyższy swoje stanowisko motywuje tym, że ból lub cierpienie zwierzęcia mają charakter zobiektywizowany i ich rzeczywisty byt jest niezależny od tego, czy sprawca wprost do nich dążył. Przedmiotem ochrony ustawowej jest bowiem ochrona zwierząt przed cierpieniem i bólem, zaś na ich doznanie nie ma w praktyce wpływu motywacja sprawcy (wyr. SN z 7.07.2020 r., II KK 222/19, LEX Nr 3049079).
\end{abstract}

Stanowisko Sądu Najwyższego ma doniosłe znaczenie w kwestii rzeczywistej ochrony zwierząt. Pozwala znacznie poszerzyć zakres czynów, które faktycznie mogą zostać uznane za znęcanie się i stanowić podstawę do poniesienia odpowiedzialności karnej. Należy mieć na względzie, że stanowisko to pozostaje niezwykle istotnym rozwiązaniem problemu zamiaru ewentualnego przy przestępstwie znęcania się z punktu widzenia przepisów materialnych ustawy o ochronie zwierząt. Koncepcja ta bazuje bowiem na definicji znęcania się nad zwierzętami zawartej w art. 6 ust. 2 u.o.z. Sądzić należy, że ustawodawca, wprowadzając we wspomnianym przepisie katalog otwarty zachowań, odwołał się do podstawowej funkcji prawa karnego - funkcji ochronnej, której celem jest ochrona dóbr o pewnej wartości przed czynami prowadzącymi do ich naruszenia. Patrząc zatem na problem dotyczący strony podmiotowej omawianych przestępstw przez pryzmat fundamentalnej funkcji prawa karnego, wydaje się uzasadnione stanowisko, by dopuścić możliwość popełnienia przestępstwa znęcania się nad zwierzętami z zamiarem ewentualnym. 
K. Kuszlewicz w odniesieniu do analizowanych orzeczeń Sądu Najwyższego wyjaśnia, że przekonanie o potrzebie wykazania zamiaru bezpośredniego w odniesieniu do woli sprawcy może wynikać ze zbyt silnej analogii do art. 207 k.k. oraz pominięcia głównego celu ustawy o ochronie zwierząt, jakim jest ochrona przed niehumanitarnym traktowaniem oraz wolność zwierząt od cierpienia (Kuszlewicz 2018). Można bowiem wskazać zarówno w doktrynie, jak i w orzecznictwie liczne przykłady stanowisk dotyczących przestępstwa znęcania się z art. 207 k.k., które dopuszczają popełnienie tego czynu jedynie z zamiarem bezpośrednim. Taki pogląd przez wiele lat akceptował Sąd Najwyższy, który w wyroku z 21 października 1999 r. stwierdził, że „znamię czasownikowe «znęca się» przesądza o ograniczeniu strony podmiotowej umyślności w postaci zamiaru bezpośredniego. Mieści się w nim bowiem chęć zadania cierpienia ofierze i dla jego realizacji samo godzenie się sprawcy na taki jego efekt nie wystarczy" (wyr. SN z 21.10.1999 r., V KKN 580/97, LEX Nr 84611). Koncepcję tę Sąd Najwyższy zaaprobował również w wyroku z 11 lutego 2003 r. (wyr. SN z 11.02.2003 r., IV KKN 312/99, LEX nr 77436) oraz w wyroku z 13 września 2005 r. (wyr. SN z 13.09.2005 r., WA 24/05, OSNwSK 2005, nr 1, poz. 1655). W orzecznictwie sądów powszechnych również można spotkać się z akceptacją powyżej przedstawionego stanowiska. Jako przykład można przytoczyć wyrok Sądu Okręgowego w Poznaniu z 6 września 2017 r., w którym sąd stwierdził, że

przestępstwo znęcania może być popełnione umyślnie i to wyłącznie z zamiarem bezpośrednim. Przesądza o tym znamię intencjonalne «znęca się», charakteryzujące szczególne nastawienie sprawcy, zawiera w sobie istnienie przewagi sprawcy nad osobą pokrzywdzoną, której nie może się ona przeciwstawić lub może to uczynić w niewielkim stopniu (wyr. SO w Poznaniu z 6.09.2017 r., XVII Ka 737/17, LEX Nr 2375899).

Tak samo do omawianego problemu odniósł się Sąd Okręgowy Warszawa-Praga w Warszawie w wyroku z 18 lutego 2019 r. (wyr. SO w Warszawie z 18.02.2019 r., VI Ka 560/19, LEX Nr 3007880). Natomiast A. Marek podkreślał, że „znęcanie jest zachowaniem intencjonalnym, co wymaga umyślności w formie zamiaru bezpośredniego" (Marek 2010). Należy jednak pamiętać również o poglądach, zgodnie z którymi możliwe jest dopuszczenie znęcania się z art. 207 k.k. zarówno z zamiarem bezpośrednim, jak i ewentualnym. Trzeba w tym miejscu wskazać na postanowienie Sądu Najwyższego z 23 maja 2017 r. (post. SN z 23.05.2017 r., III KK 157/17, LEX Nr 2329441), w którym Sąd wyraźnie dopuścił możliwość, aby przestępstwo znęcania się mogło zostać popełnione również z zamiarem ewentualnym. Orzeczenie to wpisało się w nurt orzeczniczy, zapoczątkowany uchwałą Sądu Najwyższego z 9 czerwca 1976 r., w której Sąd stwierdził, że

cechą podmiotową znęcania się jest umyślność, która w zasadzie występuje w postaci zamiaru bezpośredniego, wyrażającego się w chęci wyrządzenia krzywdy fizycznej lub moralnej, dokuczenia, poniżenia itp. - obojętnie, z jakich pobudek. Nie można jednak wyłączyć popełnienia 
niekiedy przestępstwa określonego w art. 184 k.k. z zamiarem ewentualnym (uchw. SN(CI) z 9.06.1976 r., VI KZP 13/75, OSNKW 1976, nr 7-8, poz. 86).

Ponadto stanowisko takie można spotkać również wśród przedstawicieli doktryny, między innymi w opracowaniach M. Szwarczyka (2016, art. 207). Konkludując, w oparciu o wymienione przykłady, należy stwierdzić, że analogie czynione $\mathrm{w}$ przypadku znęcania się nad zwierzętami do przestępstwa znęcania się z art. 207 k.k. nie zawsze muszą prowadzić do wniosku, że w przypadku popełnienia czynu zabronionego z art. 35 ust. la u.o.z. możliwe jest dopuszczenie jedynie zamiaru bezpośredniego, jak podkreślała to K. Kuszlewicz (2018). Rzeczywiście część autorów swoje stanowisko może zbyt dobitnie opierać na dorobku powstałym na gruncie analizy przestępstwa znęcania się z art. 207 k.k., bez uwzględnienia odmienności, jakimi cechują się przestępstwa „znęcania się” z Kodeksu karnego oraz ustawy o ochronie zwierząt. Należy jednak twierdzić, iż odwoływanie się do dorobku nauki prawa karnego, wypracowanego na podstawie art. 207 k.k., może być pomocne w rozwiązywaniu problemów związanych szczególnie ze stroną podmiotową przestępstwa opisanego w art. 35 ust. 1a u.o.z.

\section{NIEUMYŚLNE ZADAWANIE ZWIERZĘCIU BÓLU}

Nie sposób pominąć jednak opinii zaprezentowanej przez Ł. Pohla, K. Burdziaka oraz Ł. Buczka w sprawie strony podmiotowej znęcania się nad zwierzętami. Autorzy próbując rozwiązać budzące wątpliwości zagadnienie, dokonali szczegółowej analizy przepisów ustawy o ochronie zwierząt. Odwołali się do art. 6 ust 2 u.o.z., który zawiera objaśnienie pojęcia znęcania się nad zwierzętami wraz z katalogiem otwartym zachowań, które za znęcanie się mogą zostać uznane. Autorzy stwierdzili, że w powoływanym przepisie znajduje się definicja legalna omawianego zagadnienia. Będąc nią związani, wyrazili swój pogląd, że dopuszczalne jest również znęcanie się w zamiarze ewentualnym, co uzasadnili w następujący sposób:

zadawać ból i cierpienie można także nie mając zamiaru wywoływania tego rodzaju stanów rzeczy, jednak - co oczywiste - w obliczu braku w obecnym stanie prawnym przepisu kryminalizującego wywoływanie bólu lub cierpienia zwierzęcia zachowaniem nieumyślnym, niezamierzone zadawanie zwierzęciu bólu lub cierpienia pozostaje zachowaniem niezabronionym pod groźbą kary. To samo tyczy się świadomego dopuszczania do zadawania zwierzęciu bólu lub cierpienia. I w tym bowiem przypadku nie da się wykluczyć przypadków, kiedy to świadome dopuszczanie do zadawania zwierzęciu bólu lub cierpienia następowałoby w wyniku realizacji zamiaru ewentualnego czy świadomej nieumyślności (Pohl, Burdziak, Buczek 2017, 13).

Autorzy podkreślają zatem, że rozpatrując problem strony podmiotowej przestępstwa stypizowanego w art. 35 ust. 1a u.o.z. należy jedynie określić, czy możliwe jest zadawanie zwierzęciu cierpień w zamiarze ewentualnym. Twierdzą, 
że zachowanie takie jest możliwe, podobnie jak możliwe jest nieumyślne zadawanie zwierzęciu cierpień, a więc wykonywania czynności, które w art. 6 ust. 2 u.o.z. zostały uznane za znęcanie się. Ponadto w omawianym opracowaniu autorzy podali w wątpliwość również wspomniany wcześniej wyrok Sądu Najwyższego z 16 listopada 2009 r., w którym Sąd stwierdził, że przestępstwo znęcania się nad zwierzętami może zostać popełnione jedynie z zamiarem bezpośrednim, odnoszącym się do konkretnej czynności sprawczej. Autorzy postawili zarzuty, jakoby Sąd w swoich rozważaniach nie odwołał się do definicji ,znęcania się nad zwierzętami” zawartej w ustawie o ochronie zwierząt. Można mieć jednak wątpliwości co do tego zarzutu, gdyż w powoływanym wyroku Sąd stwierdził, że

w art. 6 ust. 1 został zamieszczony generalny zakaz znęcania się nad zwierzętami, po czym ustawodawca w ust. 2 sformułował definicję znęcania się w sposób dwustopniowy. Najpierw, bowiem, wskazał, że znęcanie się to zadawanie lub świadome dopuszczanie do zadawania bólu lub cierpień zwierzęciu, a następnie w czternastu punktach podał, czym w szczególności jest znęcanie się nad zwierzętami (wyr. SN z 16.11.2009 r., V KK 187/09, LEX Nr 553896).

Zatem Sąd Najwyższy odniósł się również do definicji omawianego przestępstwa, czego jednak autorzy przytaczanego opracowania zdają się nie zauważać. Ponadto przedstawiają pogląd, zgodnie z którym

pokłosiem niewłaściwie zrealizowanej przez Sąd Najwyższy wykładni tytułowej kwestii jest też niedwuznaczne sugerowanie interpretatorom, w szczególności sądom, by przy odtwarzaniu kształtu strony podmiotowej przestępstwa z art. 35 ust. 1a u.o.z. korzystali oni z dorobku nauki i orzecznictwa z zakresu odnoszącego się do strony podmiotowej przestępstwa znęcania się nad człowiekiem (Pohl, Burdziak, Buczek 2017, 14).

Autorzy wskazali zatem, że odwoływanie się w przypadku znęcania nad zwierzętami do przepisów kodeksu karnego jest niewskazane. Podkreślili, że niezbędne jest wypracowanie na gruncie ustawy o ochronie zwierząt autonomicznego stanowiska dotyczącego strony podmiotowej znęcania się nad zwierzętami, w oparciu o definicję tego czynu, znajdującą się w art. 6 ust. 1 u.o.z. W tym przypadku nie sposób odmówić autorom słuszności takiego spostrzeżenia. Bowiem sądzić należy, iż w obliczu braku ujednoliconej koncepcji dotyczącej strony podmiotowej przestępstwa znęcania się nad zwierzętami, czynienie analogii względem art. 207 k.k. może być pomocne w ocenie konkretnego stanu faktycznego. Jednak nie ulega wątpliwości, że przestępstwo stypizowane w art. 35 ust. 1a u.o.z., pomimo takiego samego znamienia czasownikowego „znęca się”, pod wieloma aspektami różni się od czynu opisanego w art. 207 k.k. Zatem chociażby ze względu na inny przedmiot ochrony art. 35 u.o.z. należy stwierdzić, że niezbędne jest w tym przypadku wypracowanie oddzielnego konceptu dotyczącego dopuszczalnych form umyślności omawianego przestępstwa. Ł. Pohl, K. Burdziak oraz Ł. Buczek w swoich rozważaniach posuwają się jednak o krok dalej, odnosząc się do nieumyślnego zadawania zwierzętom bólu. Autorzy dopuszczają konstrukcję nieumyślnego znęcania się nad zwierzętami twierdząc, że 
jakże często spotykamy się bowiem z przypadkami, w których znęcaniu się nad zwierzęciem towarzyszy krańcowo błędne, a wynikające z braku wiedzy o właściwym względem zwierząt postępowaniu i o należnym im szacunku, przekonanie człowieka, że praktykowany przezeń, nader często zwyrodniały, sposób obchodzenia się ze zwierzęciem jest sposobem traktowania go w sposób społecznie akceptowalny. Słowem, nie widać powodu, który tego rodzaju błędne opinie miałby sytuować poza zakresem prawnokarnej reglamentacji (Pohl, Burdziak, Buczek 2017, 15).

Postulat ten z pewnością w wysokim stopniu przyczyniłby się do ochrony zwierząt przed zbędnym cierpieniem. Należy zgodzić się z autorami, że taka modyfikacja dałaby wyraz zmiany stosunku ustawodawcy do zwierząt, które to obecnie traktowane są w sposób przedmiotowy. Ponadto autorzy w omawianym opracowaniu proponowali zmianę wymiaru kary za przestępstwa stypizowane w ustawie o ochronie zwierząt - za typ podstawowy miałaby grozić kara pozbawienia wolności do lat 3, za typ kwalifikowany kara pozbawienia wolności od 3 miesięcy do 5 lat, zaś za proponowany typ nieumyślny - kara grzywny, ograniczenia wolności lub pozbawienia wolności do lat 2. Należy zauważyć, że ustawą z 6 marca 2018 r. o zmianie ustawy o ochronie zwierząt oraz ustawy - Kodeks karny (tekst jedn. Dz.U. 2018, poz. 663) dokonano zmiany katalogu kar w ustawie o ochronie zwierząt. Obecnie za przestępstwa określone w ustawie o ochronie zwierząt grożą kary, które w zupełności pokrywają się z proponowanymi przez Ł. Pohla, K. Burdziaka oraz Ł. Buczka w opracowaniu z 2017 r. Może to świadczyć, że postulat wniesiony przez autorów został częściowo uwzględniony przez ustawodawcę, co pozwala mieć nadzieję, że dalsze zmiany dotyczące przestępstw przeciwko zwierzętom będą zmierzały do poszerzenia zakresu ochrony życia zwierząt, wolnego od cierpienia. Wydaje się bowiem, że postulat zaproponowany przez autorów pozostaje najlepszym rozwiązaniem problemu przedstawionego w niniejszym artykule. Wprowadzenie możliwości popełnienia przestępstw określonych w ustawie o ochronie zwierząt nieumyślnie przyczyniłoby się do znacznego rozszerzenia zakresu karalności. To z kolei miałoby wpływ na zwiększenie świadomości społeczeństwa o przestępstwach przeciwko zwierzętom. Nie ulega bowiem wątpliwości, że liczba przypadków zabijania i znęcania się nad zwierzętami nieujawnionych w statystykach przestępczości jest ogromna. Wynika to z faktu, że zwierzęta jako ofiary nie są w stanie we własnym zakresie zgłosić organom ścigania, że popełniono czyn zabroniony. Zatem poszerzająca się świadomość, że dane zachowanie wyczerpuje znamiona czynu zabronionego stanowi najbardziej skuteczne działanie, mające na celu niesienie realnej pomocy zwierzętom pokrzywdzonym w wyniku przestępstw z art. 35 u.o.z. Należy również nadmienić, iż dopuszczenie karalności konstrukcji zabijania lub znęcania się nad zwierzętami w sposób nieumyślny pewnością zdyscyplinowałoby wielu właścicieli zwierząt w związku z ciążącymi na nich obowiązkami związanymi z zapewnieniu posiadanemu zwierzęciu takich warunków życia, które nie będą powodowały jego cierpienia. Należy zatem stwierdzić, że rozwiązanie to, chociaż z pewnego punktu 
widzenia dość surowe, stanowi jedyną możliwość realnej zmiany sytuacji zwierząt obecnie. Można zatem stwierdzić, że tak szeroki zakres ochrony jest adekwatny względem istot, którym przysługuje status niemalże podmiotów prawa.

\section{UWAGI KOŃCOWE}

Wychodząc z założenia, że każda istota ma prawo do życia, w niniejszym artykule dokonano analizy przestępstw zabijania i znęcania się nad zwierzętami, określonych w art. 35 ustawy o ochronie zwierząt. Ponieważ ustawa ta jest jednym z najważniejszych aktów prawnych regulujących humanitarną ochronę zwierząt w Polsce, niezbędne było rozważenie problemów związanych z przepisami typizującymi przestępstwa, których przedmiotem ochrony jest życie zwierząt, wolne od cierpienia. Przedstawione w niniejszym artykule stanowiska zdają się jednak prowadzić do wspólnego wniosku - niezbędne jest zapewnienie szerokiej ochrony życia zwierząt. Wydaje się, że najlepszym w tym przypadku rozwiązaniem będzie dopuszczenie możliwości popełnienia przestępstwa znęcania się nad zwierzętami z zamiarem ewentualnym. Rozwiązanie to zdaje się w najlepszy sposób oddawać cel ustawy wyrażony w art. 1 u.o.z., zgodnie z którym sam fakt, iż zwierzę jako istota żyjąca jest zdolna do odczuwania cierpienia, stanowi wystarczający powód do wprowadzenia obowiązku poszanowania, opieki i ochrony przez człowieka. Warto jednak mieć również na względzie rozwiązanie proponowane przez niektórych autorów, które odnosi się do dość kontrowersyjnej konstrukcji nieumyślnego znęcania się nad zwierzętami. Wydaje się, że jest to wyjście gwarantujące możliwie najszerszy zakres ochrony życia zwierząt, wolnego od cierpienia. Należy zatem rozważyć, czy postulowane rozwiązanie nie będzie stanowiło najlepszego rozwiązania problemu strony podmiotowej przestępstwa znęcania się nad zwierzętami.

\section{BIBLIOGRAFIA}

Budyn-Kulik, Magdalena. 2021. W Kodeks karny. Komentarz aktualizowany. Red. M. Mozgawa. Warszawa: LEX Wolters Kluwer.

Budyn-Kulik, Magdalena. Katarzyna Dudka. Marek Kulik. Marek Mozgawa. 2011. „Prawnokarna ochrona zwierząt - analiza dogmatyczna i praktyka ścigania przestępstw z art. 35 ustawy z 21.08.1997 r. o ochronie zwierząt". Prawo w działaniu 9: 41-100.

Gabriel-Węglowski, Michał. 2010. „Glosa do wyroku SN z dnia 16 listopada 2009 r., V KK 187/09”. LEX/el.

Gabriel-Węglowski, Michał. 2019. „Czyn zabroniony znęcania się nad człowiekiem lub zwierzęciem a umyślny zamiar sprawcy”. LEX/el.

Kuszlewicz, Karolina. 2018. „Strona podmiotowa przestępstwa znęcania się nad zwierzętami rozumienie zamiaru bezpośredniego sprawcy. Linia orzecznicza”. LEX/el.

Marek, Andrzej. 2010. W Kodeks karny. Komentarz. Warszawa: LEX Wolters Kluwer. 
Mozgawa, Marek. 2017. W Pozakodeksowe przestepstwa przeciwko zasobom przyrody i środowisku. Komentarz. Red. M. Mozgawa. Warszawa: Wolters Kluwer.

Pohl, Łukasz. Konrad Burdziak. Łukasz Buczek. 2017. Strona podmiotowa przestępstwa znęcania się nad zwierzęciem. Warszawa: Instytut Wymiaru Sprawiedliwości.

Radecki, Wojciech. 2015. Ustawy o ochronie zwierząt. Warszawa: Difin.

Serpell, James. 1999. W towarzystwie zwierząt. Analiza związków ludzie - zwierzęta. Warszawa: Państwowy Instytut Wydawniczy.

Skuczyński, Paweł. Anna Zientara. 2012. „Prawnokarna ochrona zwierząt a filozoficzny i teoretycznoprawny problem wartości i praw podmiotowych". W Status zwierzęcia. Zagadnienia filozoficzne i prawne. Red. T. Gardocka, A. Gruszczyńska. Toruń: Wydawnictwo Adam Marszałek.

Szwarczyk, Maciej. 2016. W Kodeks karny. Komentarz. Red. T. Bojarski. Warszawa: LEX Wolters Kluwer.

Wąsek, Andrzej. 2004. W Kodeks karny. Część szczególna. T. I. Red. A. Wąsek. Warszawa: C.H. Beck.

\section{Akty prawne}

Ustawa z dnia 6 czerwca 1997 r. - Kodeks karny, Dz.U. 2020, poz. 1444 ze zm.

Ustawa z dnia 21 sierpnia 1997 r. o ochronie zwierząt, Dz.U. 2020, poz. 638.

Ustawa z dnia 6 marca 2018 r. o zmianie ustawy o ochronie zwierząt oraz ustawy - Kodeks karny, Dz.U. 2018, poz. 663.

\section{Orzecznictwo}

Wyrok SN z dnia 21.10.1999 r., V KKN 580/97, LEX Nr 846111.

Wyrok SN z dnia 11.02.2003 r., IV KKN 312/99, LEX Nr 77436.

Wyrok SN z dnia 13.09.2005 r., WA 24/05, OSNwSK 2005, nr 1, poz. 1655.

Wyrok SN z dnia 16.11.2009 r., V KK 187/09, LEX Nr 553896.

Wyrok SN z dnia 13.12.2016 r., II KK 281/16, LEX Nr 2237277.

Wyrok SN z dnia 7.07.2020 r., II KK 222/19, LEX Nr 3049079.

Wyrok SO w Piotrkowie Trybunalskim z dnia 6.03.2018 r., IV Ka 73/18, LEX Nr 2503938.

Wyrok SO w Poznaniu z dnia 6.09.2017 r., XVII Ka 737/17, LEX Nr 2375899.

Wyrok SO w Warszawie z dnia 18.02.2019 r., VI Ka 560/19, LEX Nr 3007880.

Uchwała SN(CI) z dnia 9.06.1976 r., VI KZP 13/75, OSNKW 1976, nr 7-8, poz. 86.

Postanowienie SN z dnia 23.05.2017 r., III KK 157/17, LEX Nr 2329441.

(C) by the author, licensee Łódź University - Łódź University Press, Łódź, Poland. This article is an open access article distributed under the terms and conditions of the Creative Commons Attribution License CC BY-NC-ND 4.0 (https://creativecommons.org/licenses/by-nc-nd/4.0/) 